МАТЕМАТИЧЕСКАЯ МОДЕЛЬ ОЦЕНКИ ПОГРЕШНОСТИ ОПРЕДЕЛЕНИЯ ВЫСОТЫ ПРИ ВНЕШНЕМ ЦЕЛЕУКАЗАНИИ В АРТИЛЛЕРИЙСКОМ ПОДРАЗДЕЛЕНИИ С ПОМОЩЬЮ ЛЕТАЮЩЕЙ ПЛАТФОРМЫ

В.Н. Тарасов, Ю.М. Бусяк, Ю.В. Мирошниченко, В.В. Яковенко, О.В. Королёва

В работе предложен алгоритм определения высоты расположения иели с помощью летающей платформы. Проведен анализ погрешностей при ее определении. Исследована зависимость погрешностей определения высоты иели от взаимного расположения пункта наблюдения, платформы и цеели.

Ключевые слова: высота, летающая платформа, оченка погрешностей

\title{
THE ERROR ESTIMATION OF THE HEIGHT FINDING WITH EXTERNAL TARGET DESIGNATION IN THE ARTILLERY UNIT WITH THE AID OF FLYING PLATFORM
}

V. Tarasov, Y. Busiak, Y. Myroshnyhenko, V. Yakovenko, O. Koroliova

The algorithm of the target height finding with the aid of the flying platform has been offered in the article. Analysis of errors when defining it has been undertaken. Dependencies of target defining errors on the positional relationship of the observation point, platform, and target have been examined.

Key words: height, flying platform, error estimation.

\section{УДК 621.396}

\author{
П.П. Ткачук ${ }^{1}$, Д.І. Могилевич ${ }^{2}$ О.К. Климович ${ }^{1}$ \\ ${ }^{1}$ Академія сухопутних військ імені гетьмана Петра Сагайдачного, м. Львів \\ ${ }^{2}$ Військовий інститут телекомунікацій та інформатизащії Національного технічного \\ університету України «Киӥвський політехнічний інститут», м. Київ
}

\section{ЗАСТОСУВАННЯ ПЕРСПЕКТИВНИХ ІНТЕЛЕКТУАЛЬНИХ СИСТЕМ УПРАВЛІННЯ ПІД ЧАС СТВОРЕННЯ ЄДИНОЇ АВТОМАТИЗОВАНОЇ СИСТЕМИ УПРАВЛІННЯ ЗБРОЙНИХ СИЛ УКРАЇНИ}

\begin{abstract}
Стаття присвячена питанню застосування перспективних інтелектуальних систем управління під час створення Сдиної автоматизованої системи управління Збройних Сил Украйни з метою досягнення якісно нового рівня системи управління та підвищення ефективності управління життєдіяльністю, підготовкою та застосуванням Збройних Сил України. Розроблені рекомендації спрямовані на удосконалення організації методів роботи посадових осіб органів і пунктів управління.
\end{abstract}

Ключові слова: Сдина автоматизована система управління, автоматизована система управління, гібридні інтелектуальні системи.

\section{Вступ}

Постановка проблеми. Аналіз останніх досліджень i публікацій. Виходячи із завдань Державної комплексної програми реформування та розвитку Збройних Сил України на 2012-2017 роки, Державної цільової оборонної програми розробки озброєння та військової техніки Збройних Сил України на 2012-2017 роки та Концепції реформування та розвитку Збройних Сил України на період до 2017 року робота щодо розвитку засобів автоматизації в системах управління та інформатизації Збройних Сил України проводиться в рамках створення Єдиної автоматизованої системи управління Збройними Силами України. Результати відповідних заходів призвели до повної цифрової прив'язки стаціонарних інформаційно-телекомунікаційних вузлів оперативної і часткової цифрової прив'язки тактичної ланок управління Збройних Сил України [1-3].

Метою роботи $\epsilon$ підвищення ефективності функціонування Сдиної автоматизованої системи управління (САСУ) за рахунок застосування перспективних інтелектуальних систем управління військового призначення. Для прийняття раціонального варіанта побудови та функціонування автоматизованих систем управління потрібен інструмент, що дозволить у динаміці управління процесом інформаційного обміну визначити очікувану якість функціонування системи. 


\section{Виклад основного матеріалу}

В сучасних умовах управління військами неможливе без використання автоматизованих систем. Причини цього обумовлені факторами збільшення вогневої можливості військ; збільшення маневреної можливості військ, що призводить до ускладнення управління; великого просторового розмаху сучасних операцій, що призводить до значного збільшення обсягів інформації, які надходять в органи управління військами (рис. 1). Таким чином, 3 одного боку, обсяг роботи командирів і штабів зріс, а $з$ іншого боку час на виконання цієї роботи скоротився.

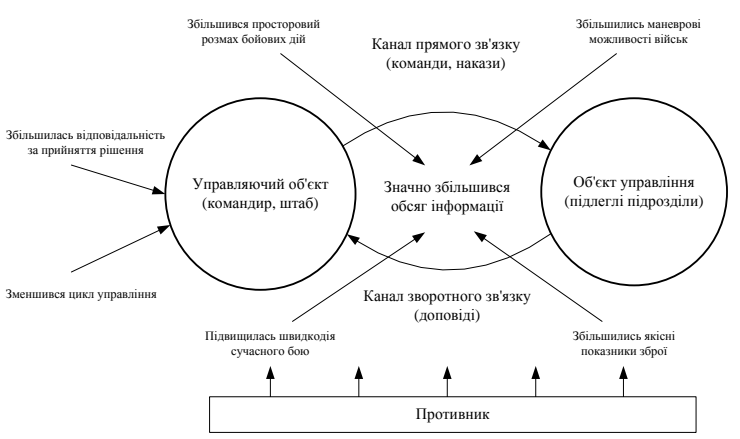

Рис. 1. Узагальнена модель управління та фактори, що впливають на неї

Розв'язання цього протиріччя може бути досягнуто тільки на основі автоматизації управління військами, що являє собою комплекс заходів, які забезпечують передачу функцій управлінської діяльності командирів і штабів технічним засобам та охоплюють процеси одержання, передачі, перетворення і використання інформації.

Підгрунтям для автоматизації є впровадження засобів обчислювальної техніки, на основі яких створюються автоматизовані системи управління військами. Метою використання автоматизованих систем управління $є$ підвищення ефективності бойових дій військ, а їі складовими частинами є підсистема управління, інформаційна підсистема, підсистема зв'язку і передачі даних. Перші дві підсистеми є функціональними, зв'язаними з рішенням задач 3 досягнення основної мети й істотно залежними від специфіки конкретної автоматизованої системи управління (АСУ), а підсистема зв'язку і передачі даних менше за інших пов'язана зі специфікою АСУ і має більшу узагальненість.

В теперішній час підсистему зв'язку і передачі даних складають інформаційно-телекомунікаційні мережі, що являють собою сукупність інформаційнотелекомунікаційних вузлів, локальних обчислювальних мереж, окремих робочих станцій та засобів зв'язку. Інформаційно-телекомунікаційна мережа $є$ важливою компонентою АСУ і повинна забезпечувати високошвидкісний, надійний та достовірний обмін інформацією. Відповідно до прийнятої концепції побудови САСУ, що передбачає будівництво автоматизованих систем управління військами на основі принципів уніфікації і стандартизації, основу інформаційно-телекомунікаційної мережі складають комп'ютерні мережі з відкритою архітектурою, які являють собою ядро сучасних автоматизованих систем управління, платформу для створення багаторівневих систем управління військами.

Інформаційно-телекомунікаційна мережа являє собою складну систему, яка функціонує в рамках більшої системи - системи управління військами і в силу свого цільового призначення впливає на якість управління та ефективність бойових дій. Із цим пов'язана принципова можливість оцінки результатів функціонування інформаційно-телекомунікаційної мережі на різних рівнях за показниками бойової ефективності, ефективності системи управління військами, власної внутрішньої ефективності.

Необхідність розвитку процесів управління Збройними Силами України обумовлює розробку інформаційних моделей опису функціонування військових інформаційно-телекомунікаційних систем. Протягом наступних років пріоритет буде наданий розвитку функціонування САСУ Збройними Силами України за рахунок розробки інформаційних моделей, аналітичних і розрахункових завдань, впровадженню на їхній основі автоматизованої системи підтримки прийняття рішень для органів управління військами.

На сьогодні інформаційно-телекомунікаційній системі притаманні такі риси, як багатофункціональність, що випливає 3 необхідності передавання різних видів інформації; складність структурної організації і алгоритмів функціонування; наявність великої кількості підсистем і елементів, які входять у систему, та їх тісний взаємозв'язок; імовірнісний характер процесів функціонування системи, який обумовлений випадковими і навмисними змінами параметрів середовища, а також невизначеним характером потоків інформації; великі просторові габарити і динамічність.

У зв'язку зі складністю та великомасштабністю інформаційно-телекомунікаційної системи оцінка їі ефективності в методологічному плані повинна базуватися на основних положеннях теорії складних систем, теорії ефективності, теорії ймовірностей, теорії масового обслуговування, теорії дослідження операцій і системного аналізу. Виникає гостра необхідність застосування основних типів інтелектуальних систем управління: інформаційних систем, систем підтримки прийняття рішень, систем, що навчають, експертних систем та гібридних систем [4-8].

В залежності від процедур, за допомогою яких інтелектуальна система оволодіває новими знаннями та новими видами діяльності, планує та реалізує 
свою поведінку, найбільш доцільно було б застосувати гібридні інтелектуальні системи, в тому числі інтелектуальні системи планування та оперативного управління в системах військового призначення. Гібридні інтелектуальні системи являють собою комбінацію експертних систем, системи імітаційного моделювання, системи, яка навчає, розрахункового блока та інших систем, тобто даний клас систем об'єднує можливості вказаних вище типів систем (рис. 2).

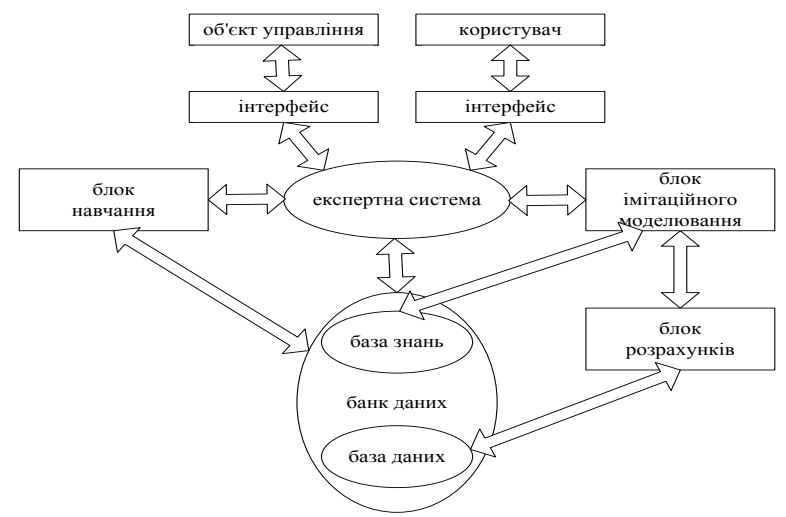

Рис. 2. Структурна схема гібридної інтелектуальної системи

Пропонується використати перспективні гібридні інтелектуальні системи в практичній діяльності органів управління зв'язком окремої механізованої бригади. Впровадження відповідних систем дозволяє підвищити оперативність пошуку та вибору раціонального варіанта САСУ з одночасним прогнозом найбільш істотних властивостей АСУ.

Можливості групи планування та оперативного управління з використання запропонованих систем в умовах обмеженого часу зможуть за допомогою автоматизації процесів управління значно підвищити рівень управління окремої механізованої бригади. Результати досліджень (підготовка баз даних для розрахунків, необхідність вирішення завдань, пов'язаних з вибором раціонального варіанта АСУ) свідчать про те, що для організації роботи групи планування та оперативного управління необхідно використати командно-штабну машину з автоматизованими робочими місцями в локальній мережі штабу окремої механізованої бригади (рис. 3).

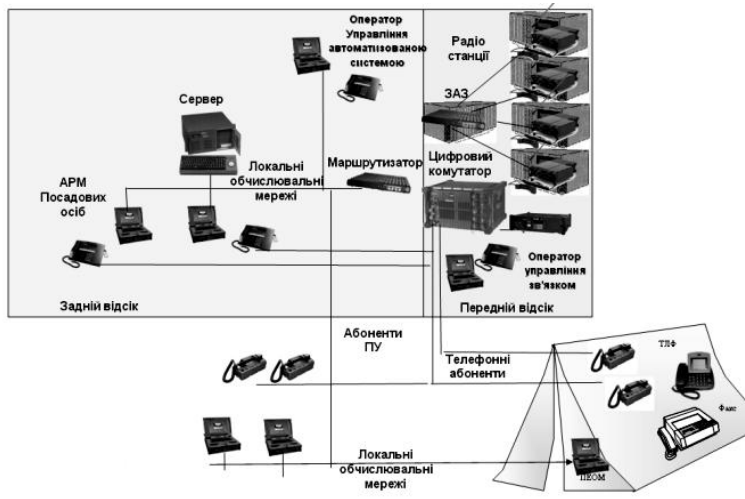

Рuc. 3. Локальна обчислювальна мережа командноштабної машини окремої механізованої бригади

\section{Висновки}

Отже, застосування перспективних інтелектуальних систем управління військового призначення при створенні САСУ Збройних Сил України дозволить забезпечити функціонування автоматизованих систем управління тактичної ланки управління. Запропоновані рекомендації спрямовані на підвищення ефективності функціонування АСУ окремої механізованої бригади. Об'єднання можливостей використання всіх інформаційних, програмних, обчислювальних ресурсів автоматизованих систем управління та розгалуженого телекомунікаційного середовища 3 метою забезпечення взаємозв'язку командирів і штабів 3 підлеглими військами для отримання достатньої інформації протягом необхідного часу незалежно від розташування та відстані дозволить реалізувати ідею побудови єдиного військового інформаційного середовища.

\section{Список літератури}

1. Біла книга - 2012. Збройні Сили Украӥни. - К.: Міністерство оборони України, 2013. - 74 с.

2. Морозов А.О. Ідеологія САСУ Збройних Сил Украӥни // Оборонний вісник. - 2012. - №1. - C. 8-11.

3. Фролов В.С. Структурно-логічна схема Єдиної автоматизованої системи управління Збройних Сил України // Наука і оборона. - 2012. - №1. - С. 15-23.

4. Тарасов В.О., Герасимов Б.М., Левін I.O., Корнійчук В.О. Інтелектуальні системи підтримки прийняття рішень: Теорія, синтез, ефективність. - Киї: MAKHC, 2007. - $336 c$.

5. Герасимов Б.М., Дивизинюк М.М., Субач И.Ю. Системы поддержски принятия решения: проектирование, применение, оценка эффективности. - С.: СНИЯЭиП, 2004. - 320 c.

6. Герасимов Б.М., Тарасов В.А., Токарев И.В. Человекомашинные системы. Принятие решений с элементами искусственного интеллекта. - К.: Наукова думка, 1993. $320 \mathrm{c}$.

7. Теория управления в системах военного назначения / Под редакцией И.В. Котенко. - М.: МО, 2001. $320 \mathrm{c}$.

8. Новые сетевые технологии в системах управления военного назначения / Под редакиией П.И. Буренина. СПб.: ВУС, 2000. -200 c.

Рецензент: д.т.н., с.н.с. В.М. Корольов, Академія сухопутних військ імені гетьмана Петра Сагайдачного, м. Львів. 
ИСПОЛЬЗОВАНИЕ ПЕРСПЕКТИВНЫХ ИНТЕЛЛЕКТУАЛЬНЫХ СИСТЕМ УПРАВЛЕНИЯ ВО ВРЕМЯ СОЗДАНИЯ ЕДИНОЙ АВТОМАТИЗИРОВАННОЙ СИСТЕМЫ УПРАВЛЕНИЯ ВООРУЖЕННЫХ СИЛ УКРАИНЫ

\author{
П.П. Ткачук, Д.И. Могилевич, О.К. Климович
}

Статья посвящена вопросу применения перспективных интеллектуальных систем управления во время создания Единой автоматизированной системы управления Вооруженных Сил Украины с иелью достижения качественно нового уровня системы управления и повышения эффективности управления жизнедеятельности, подготовки $u$ применения Вооруженных Сил Украины. Разработаны рекомендации, которые направлены на усовершенствование организации методов работы должностных лии органов и пунктов управления.

Ключевые слова: Единая автоматизированная система управления, автоматизированная система управления, гибридные интеллектуальные системы.

\title{
USE OF PERSPECTIVE INTELLECTUAL CONTROL THE SYSTEM DURING CREATION SINGLE AUTOMATED CONTROL THE SYSTEM OF THE ARMED FORCES OF UKRAINE
}

\section{P. Tkachuck, D. Mohylevych, O. Klymovych}

The article is devoted to the question of application of perspective intellectual control the system during creation of Single automated control system of the Armed Forces of Ukraine with the purpose of achievement high-quality of new level of control system and increase efficiency of management of vital functions, preparation and application of Armed Forces of Ukraine. Recommendations for improvement of organization of officials work on command points are developed.

Key words: single automated control system, automated control the system, hybrid intellectual systems.

УДК $351.824 .11+621$

В.М. Філь ${ }^{1}$, В.О. Юрченко ${ }^{2}$, Ю.О. Фтемов ${ }^{3}$

${ }^{1}$ Національний університет оборони Украӥни, м. Київ

${ }^{2}$ Інститут державного управління у сфері ичивільного захисту, м. Київ

${ }^{3}$ Академія сухопутних військ імені гетьмана Петра Сагайдачного, м. Львів

\section{ПРОБЛЕМИ ЕЛЕКТРОТЕХНІЧНОГО ЗАБЕЗПЕЧЕННЯ В СТРУКТУРНО- ЯКІСНІЙ МОДЕРНІЗАЦІЇ ЗС УКРАЇНИ ТА СИЛ ЦИВІЛЬНОГО ЗАХИСТУ ДЕРЖАВНОЇ СЛУЖБИ УКРАЇНИ З НАДЗВИЧАЙНИХ СИТУАЦЙ}

Проведений аналіз керівних документів з питань електротехнічного забезпечення; визначені проблемні питання подальшої структурно-якісної модернізації ЗС України та Державної служби Украӥни з надзвичайних ситуацій стосовно електротехнічного забезпечення; визначені можливі напрямки їх вирішення та його особливості.

Ключові слова: електротехнічне забезпечення, електротехнічні засоби, енергозбереження, сили цчивільного захисту.

\section{Постановка проблеми}

Питання якісного функціонування всіх структурних складових ЗС України, сил цивільного захисту Державної служби України з надзвичайних ситуацій (ДСНС), а також підприємств, установ та організацій різних галузей національної економіки, зниження рівня аварійності, техногенної безпеки військових об'єктів та промисловості тісно пов'язано 3 системою електропостачання військ та об'єктів як енергетичною основою функціонування будь-яких складових системи, а широке впровадження ресурсозберігаючих технологій дедалі стає актуальнішим. Неможливо сьогодні уявити будь-яку військову частину або аварійно-рятувальний загін, які могли б нормально функціонувати в бойових умовах, в умовах мирного часу, під час ліквідації надзвичайних ситуацій або аварійно-рятувальних та інших невідкладних робіт без наявності енергоносіїв, у тому числі електроенергії. Кількість та показники якості останньої безпосередньо будуть впливати на підтримання постійній готовності військ, зброї та сил цивільного захисту 